付着強度に関する研究 (第2 報)

（復数配管で、その本数と間隔を変化させた場合）

正会員 ○鈴 木 豊 郎*

同松原 光 彦**

$\S 1$. 序

第 1 報（35年10月大会）に於て、“練置時間及び材令 の影響について（単筋）、発表したが、今回第 2 報とし て、“復数配筋で本数と間隔及び配列を変化させた時” その影響を調べた結果を発表する。

\section{§2. 実験の方法}

\section{1 実験計画}

コンクリートタテ打とヨコ打の 2 つのブロックに分げ て行ない、ヨコ打の場合は、第1図(a)に示す様に上端 と下端に配筋した。

2.2 諸条件

(1) 供試体の形状
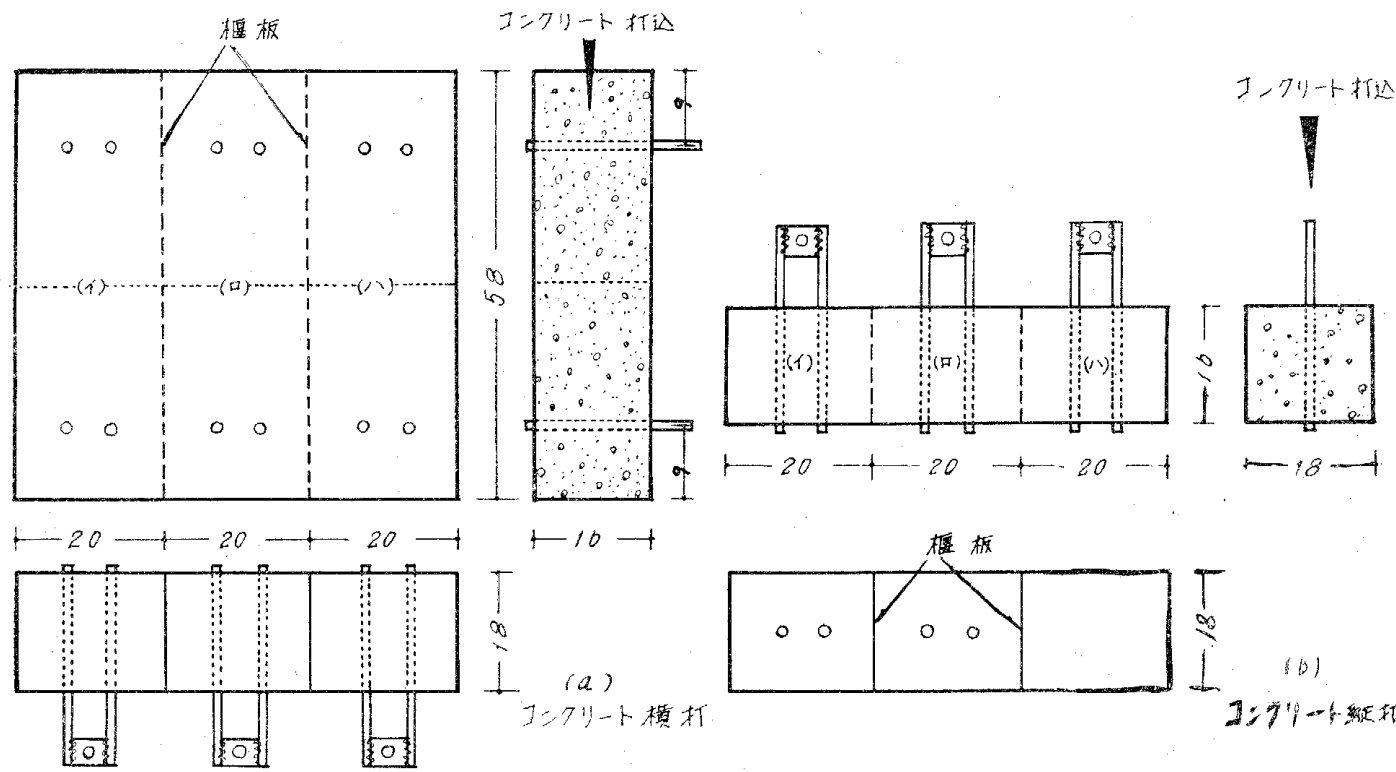

供鿁体型样到枧

第 1 図

コンクリ一ト檘朾
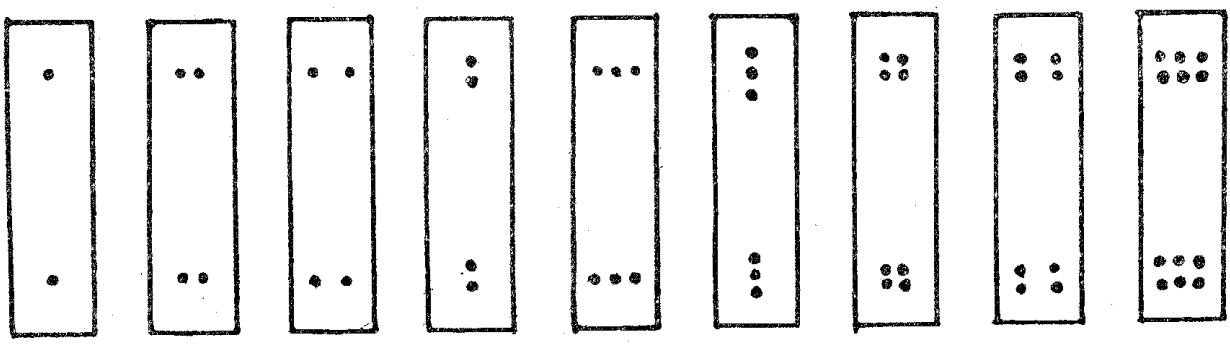

コンクリート 徒打
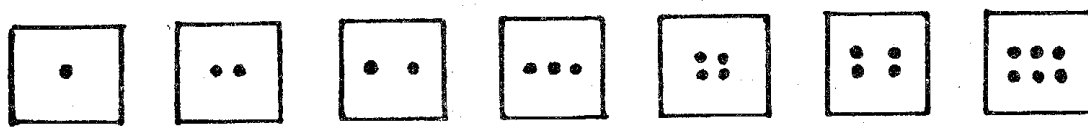

(A)

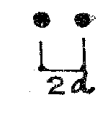

(ㅁ)

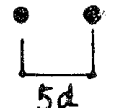

供試体の種 類

第 2 図

*大阪工業大学建築学科講師 ** 同助手 


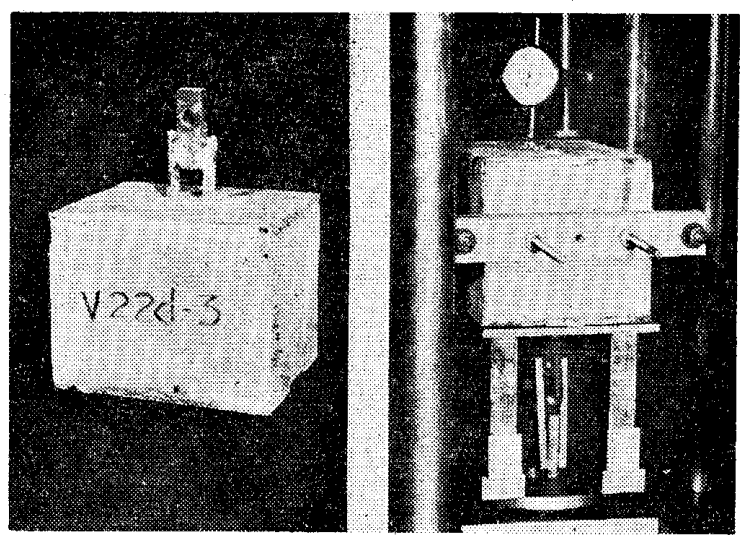

写真 1 代試体と試駼装置

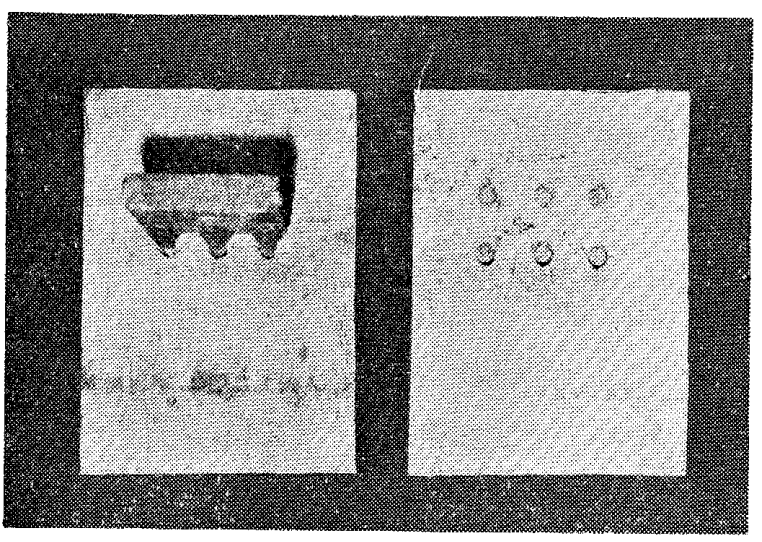

写真 $2 \mathrm{HH} 62 \mathrm{du}$

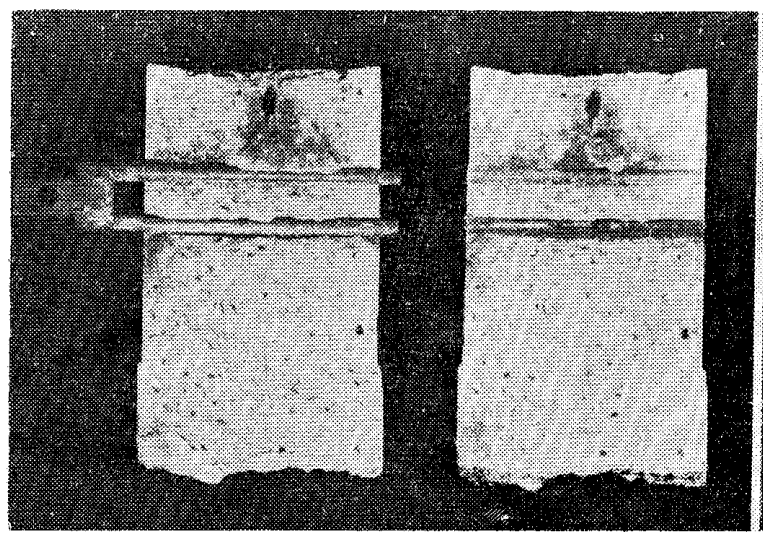

写真 3 コンクリートの沈多 (左 HV $22 \mathrm{dv}$ ・在 HV $32 \mathrm{du}$ )

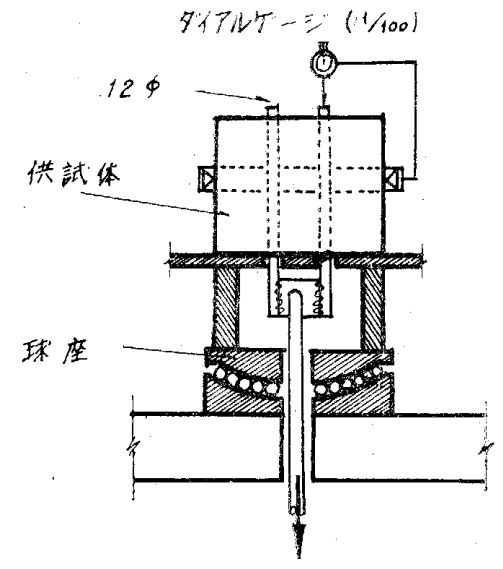

第 3 図 引拔試験装置

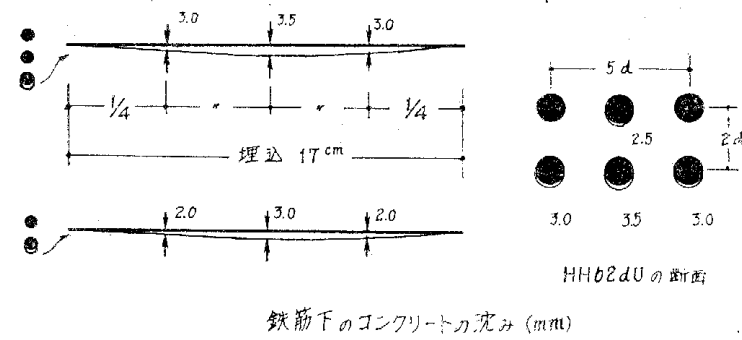

第 4 図

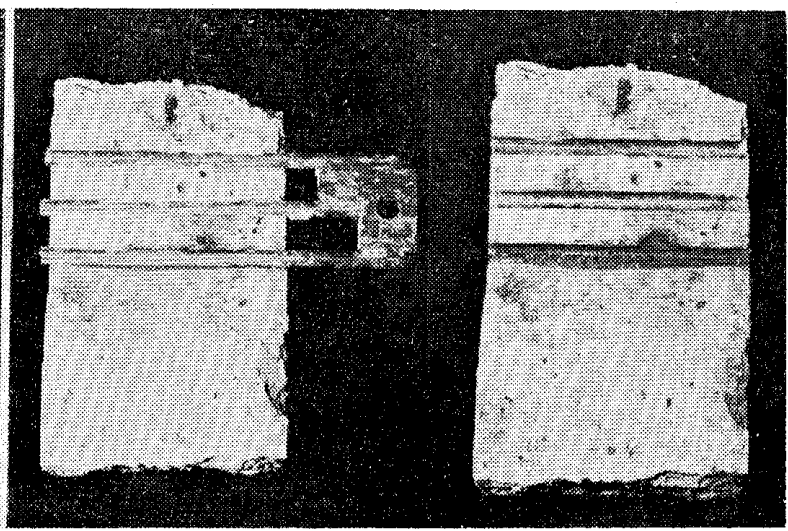

(3) 铁筋の加工江つて

コンクリートのヨコ打の場合 $58 \times 20 \times 16 \mathrm{~cm}$ (三連)、 夕テ打の場命 $16 \times 20 \times 18 \mathrm{~cm}$ (三連) の 2 䄽類とし、配

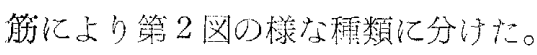

(2) 倛武体作製方法

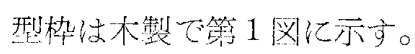

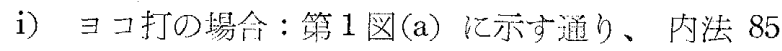

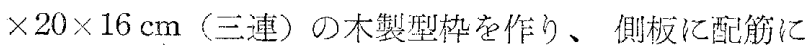

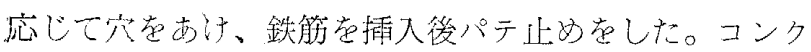
リートの立填は、4層に分けて行ない、各層共10回つき ¿した。

ii) 夕テ打の場合：第 1 図(b) 注示通り、内法 16 $\times 20 \times 18 \mathrm{~cm}$ (三連）の木製型桦学朋い、コンクリート 就 2 層に犼て古填し备 10 回つきとした。

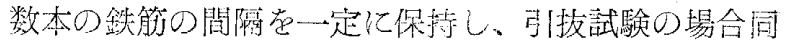

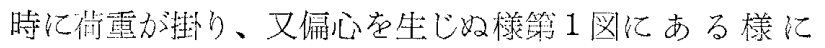

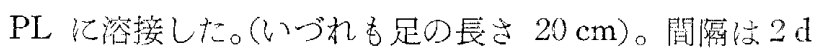
と $5 \mathrm{~d} 02$ 種類である。 $\mathrm{d}$ : 鉄筋径 $(12 \mathrm{~mm} \phi)$

(4) 配筋汇つて

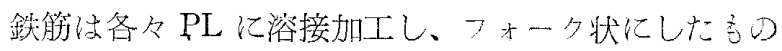

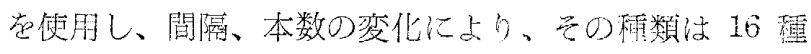
であり各々 3 個宛作製した。鉄筋はヨコ打のときは型染 にセットして後パテ止わにした。

(5) 供試体の養生

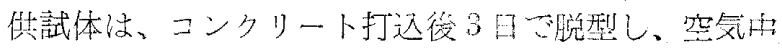
湿潤養生党行つた。 
(6) 試験方法

いづれも引抜試験で、50tアムスラ一型万能試験機を 便用し、写真 1 及び第 3 図に示す様に七ットし、コンク りートと鉄筋の柏互の滑りとダイアルゲーシ (1/100) で 続みとり、初滑動時、最大㭙の滑りを測定した。材令は いづれも2週である。

(7) 值用材料

コンクリート：生コンクリートを使肘し、細骨材 $5 \mathrm{~mm}$ 以下、粗骨材 $10 \mathrm{~mm}$ 以下、調合は次の通り 調全 $\left(\mathrm{m}^{3}\right.$ 当重量) :

$$
\begin{array}{crrlll}
\text { セメント } & \text { 砂 } & \text { 砂暞 } & \text { 水 } & \text { W/C } & \text { スランプ } \\
340 & 880 & 883 & 218 & 64 \% & 23.1 \mathrm{~cm}
\end{array}
$$

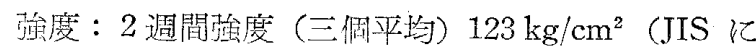
依る)

$\$ 3$. 军駼結果

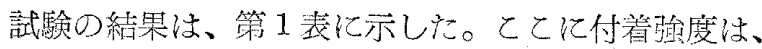
次式

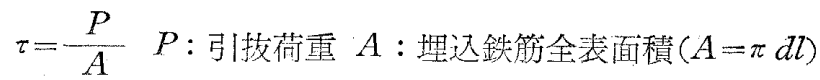
で求めたものであり、表中の数值は、各 3 個の供試体の 平均值である。以下文中付着強度は、最大付着強度老示 すものとする。

\section{§4. 実験結果の検討}

4.1 コンクリートの沈みについて

一般に、銠筋を我平に埋达んだ場合の付着強度は、鉛 直に埋込んだ場合のそれの $1 / 2 \sim 1 / 3$ 程度迄低下し、鉄筋 が水平に埋込まれ、而端居定された場合、コンクリー トの沈みにより空陌を生ずるといわれる。今回の実験で 復数配筋の場合も例にもれず、供試体中には、鉄筋に沿 つて見通せる程のものもあつた。深さ $58 \mathrm{~cm}$ のので、 上下端に配筋したが、結果は前者の方の付着強度は、著 しく小さい值である。

\section{1 鉄筋の位置について（ヨコ打の場合）}

第 2 表より明らかな様に上端の付着独度は、下端のそ れの 20〜30\% 程度である。これは、鉄筋の埋込まれた 位置、即ち鉄筋下のコンクリートの量に関係し、上端に 执いてはコンクリートの沈子が著しく、又浮水や気泡等 の集合により空陌を生じ、接着面積の減少によるもので あると栲えられる。試験を終了したものについて、供試 体在铁筋に沿つて分亚して子ると、写真 3 亿見られる様 な絬果在見た。コンクリートの下りを测定し図に示すと 第 4 図の様になり、西端より中央に加けて大きくなり、 最大で $3.0 \sim 3.5 \mathrm{~mm}$ 程度であり、断面については、鉄 筋の下側は完全に分離し、上側で $1 / 2 \sim 1 / 3$ 程接着してい るのみでかつた。鉄筋下のコンクリート面汶、気泡等で 多孔質になつている。下端筋については、その影留は殆 んぞ見られず、嚾少であるが空腺を生じているのもあつ た。ヨコ打の場合には、鉄筋の位置に上つて大差痤生ず

\begin{tabular}{|c|c|c|c|c|c|}
\hline & 型材 & $\begin{array}{l}\text { 初滑付着 } \\
\text { 強度 } \mathrm{kg} / \mathrm{mm}\end{array}$ & 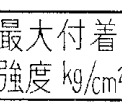 & 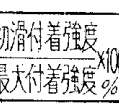 & 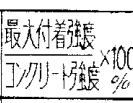 \\
\hline$-422 \mathrm{dl}$ & $\cdots$ & 1.0 & 2.3 & 48.2 & 1.8 \\
\hline $122 \mathrm{~d} 0$ & $\because$ & 10.9 & 12.7 & & 10.3 \\
\hline $25 \mathrm{dl}$ & $\because$ & 1.9 & 2.2 & 85.0 & 1.8 \\
\hline $25 \mathrm{~d}$. &.. & 11.8 & 13.4 & 88.0 & $11: 0$ \\
\hline $1,32 \mathrm{du}$ & $\cdots$ & - & 1.5 & - & - \\
\hline $132 \mathrm{dD}$ & 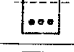 & 4.4 & 7.4 & 60.0 & 6.0 \\
\hline $\mathrm{H} 42 \mathrm{dJ}$ & $\because:$ & 1.8 & 3.1 & 58.2 & 2.6 \\
\hline $42 \mathrm{~d} 0$ & :: & 7.5 & 10.0 & 75.0 & 8.1 \\
\hline $\mathrm{H} 45 \mathrm{dU}$ & $\therefore$ & 5.2 & 5.6 & 93.1 & 4.6 \\
\hline $45 \mathrm{~d} 0$ & $\because:$ & 8.1 & 12.4 & 64.9 & 10.1 \\
\hline $62 \mathrm{dJ}$ & 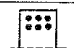 & 0.6 & 3.2 & 18.0 & 2.6 \\
\hline $4+162 \mathrm{dD}$ & $\$ 38$ & 8.2 & 10.3 & 79.7 & 8.5 \\
\hline $\mathrm{HI}$ & $\theta$ & $\longrightarrow$ & 0.4 & 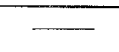 & 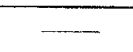 \\
\hline & 5 & 11.6 & 14.5 & 80.0 & 11.8 \\
\hline $22 \mathrm{dU}$ & 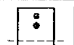 & 2.3 & 4.2 & 55.5 & 3.4 \\
\hline & 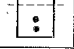 & 12.4 & 14.0 & 8.4 & 11.4 \\
\hline & 1 & 3.0 & 5.5 & 54.2 & 4.4 \\
\hline & $\because$ & 12.0 & 15.0 & 80.0 & 12.2 \\
\hline & $\cdot \cdot]$ & 13.6 & 14.2 & 96.5 & 11.5 \\
\hline & 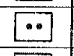 & 6.7 & 12.0 & 56.0 & 10.0 \\
\hline $5 \mathrm{~d}$ & $\because$ & 7.9 & 11.7 & 67.2 & 9.5 \\
\hline $2 d$ & $\ldots$ & 7.3 & 10.8 & 68.1 & 9.5 \\
\hline$\overline{V 42 d}$ & $\because: 8$ & 5.1 & 9.6 & 53.1 & $7 \overline{8}$ \\
\hline$V 45 d$ & $\because:$ & $13.1 *$ & $15.2 \%$ & 86.2 & 12.3 \\
\hline & B8: & 7.7 & 11.6 & 66.5 & 9.4 \\
\hline
\end{tabular}

第 1 表 実験結果一覧

\begin{tabular}{|c|c|c|c|}
\hline 配筋 & 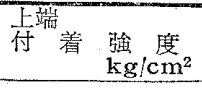 & 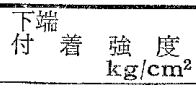 & $\begin{array}{l}\text { 上端 } \\
\text { 端 }\end{array} \times 100$ \\
\hline : & 4.2 & 14.0 & 30.0 \\
\hline 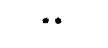 & 2.3 & 12.7 & 17.8 \\
\hline$\vdots$ & 5.5 & 15.0 & 36.2 \\
\hline$\ldots$ & 1.5 & 7.4 & 19.7 \\
\hline$\cdot . \widehat{\frac{8}{Z}}$ & \multicolumn{3}{|c|}{13.4} \\
\hline
\end{tabular}

第 2 表

（註）：コンクリート打达方向に平行，・直角

る。

4.3 鉄筋の配列について

i) ヨコ打の場合

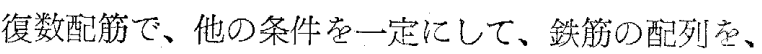
コンタリート打达方向に平行と直争の 2 種についてみる と、結果法第 2 表に示す通り、世端筋の付着学度流、下 端のそれの

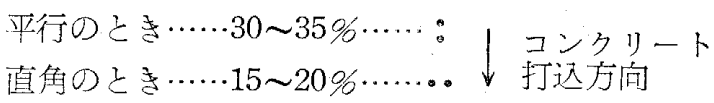

程度となり、コンクリート打込方向に淔角に配列した場 合の付着強度の減少力䫏著である。とれは、第4 図及ご 写真 2,3 亿示守様に、鉄筋を平行に配列した場合は。 各鉄筋の下に空除が生じ、直角に配列したものは、一番 下の鉄筋下に大きな空隍を生ずるが比順次影響が少す 
くなつていることから説明しうる。直角佂配列した場合 には、一番下の鉄筋が号の上のコンクリートの沈久在抑

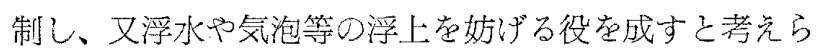
机る。てれらより、上端でコンクリートの打込方向に平 行な配列のものの付着強度の減少は、コンクリートの沈 み等の影響が大きく、又コンクリート自体の上端での強 度の低下も加光教光るとき当然のととと思われる。

ii）タテ打の場合は影響は少ない。

4.4 鉄筋の本数の変化们つて

i) ヨコ打の場合

他の条件一定で本数のみ変化させたとき、今鉃筋は、 打这方向に直角で、2本 (・) 亿対し、2列にして 4 本 $(:$ : )、各々間隔蛙の 5 倍のものでは、付着強度は、 上端では 2 倍程に増加している。乙れは、: : の様に2 列に配列したときは、前項で説明した様に、下段のもの は空陌を生じるが上段に法影響が少ない為であり、本数 の增加と共に、接着面積も增加しているからである。同 様に、3本と6 本此較すると殆んど同じ傾问にある。 次に 2 本と 3 本 (一列) を比べると、本数が增加、即表 面積が増加しているのに、逆付付着強度が下つている。 てれも前と同㥞に、各筋下の空陌の影響が大きく、特に 3 本 1 列配筋の場合には、それが大きく作用していると 思う。コンクリートヨコ打で上端に於て打这方向に直角 飞配列をるとき、同じ本数の場合は、1段より 2 段飞配 列する方が有利であると考えられる。しかし下端につい
ては大差はない。

ii) タテ打のとき

との場合法、本数の增眈につ礼て僅少ながら付着強度 は低下する傎向にあった。

\section{§. 結 び}

以上の実颐結果を総合して考光ると、復数配筋の場合、 コンクリートの充填を允分にしたとき、鉛直埋込筋の付 着強度に対する、鉄笳の間隔、配列、本数の影響は、少 ないが、そ机付して、水平の場合、特に上端に於て は、ブリージング等により、コンクリート自体の強度が 低下し勝ちである上に、鉄筋下のコンタリートの沈みに よる空陌、コンクリートの允填の難等から、とれらの影 響は大きい。本英駼にても水平鉄筋（上端に於ける）付 着強度は、鉄筋の配列、本数、間隔等によつて凡そ $1 / 4$ に迄低下することを示している。

謝辞 : 本実駼際して生コンクリートを御提供頂いた 大阪宇部コンクリート工業に感謝の意を表すと共に、実

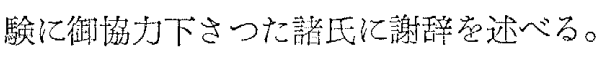

\section{[参考文献]}

1）狩野 春一：生コンクリートの沈下による鉄筋付着強度 の減少と、2，3 の対策。学会䜽文集 49

2）加藤六美 : 鉄筋の付着亚びに定看に対する、2,3 の注意 学会報告集 22 .

3) S.J. Chamberlin : Spacing of Reinforcement in Beams: 